\title{
Spatial and Temporal Analysis of the Snow Line in the Alps Based on NOAA-AVHRR Data
}

\author{
Stefan Wunderle, Bern, Marcel Droz, Bern, Hannes \\ Kleindienst, Base ${ }^{1)}$
}

\section{Introduction}

Snow cover is an important feature of mountainous regions like the Alps. Depending on the latitude, the higher altitudes are completely covered by snow for several months a year. The high surface albedo of snow greatly influences the local climate, decreasing the surface net radiation and thus the energy transfer. In addition, snow cover is a relevant factor not only for the development of ecosystems, but also for human activities like hydropower generation or ski tourism. The snow line is an important indicator of snow coverage. Its spatial fluctuation reflects climatic behavior, indicating a tendency either towards cold and/or wet conditions or towards a warmer climate.

For many years now, satellite data has been widely used in snow hydrology at a regional to continental scale (BAumgartner et al. 1991; CARroll 1990; EHrLer \& SCHAPER 1997; KLEINDIENST et al. 1999; Rango 1993; Ranzi et al. 1999; Pietroniro \& Leconte 2000). However, only few publications deal with the use of satellite data for assessing snow line elevation (e.g. SEIDEL et al. 1997). The major advantages of NOAA-AVHRR data are that a sufficiently high repetition rate is ensured and areas as large as the Alps are easily covered. The aim of this paper, therefore, is to show the applicability of NOAA-AVHRR data for analyzing the snow line level at an alpine scale.

\section{Snow line derivation using satellite data}

\subsection{Definition of the snow line in satellite images}

Snow maps derived from satellite data are pixel-based representations of snow-covered areas. Due to a spatial resolution of between a few hundred meters and a kilometer, a pixel, although either classified as 〈snow〉 or «no-snow, often consists of snow-covered and snowfree parts. In theory, the snow line defines the line separating snow-covered from snow-free areas. However, due to the patchiness of the snow cover edge, no distinct line can be drawn. Instead, the snow line may be seen as a more or less narrow belt representing a zone of approximately $50 \%$ snow coverage (WMO World Meteorological Organization - in SEIDEL et al. 1997). As satellite data interpretation deals with mixed pixels, the above definition of the snow line is appropriate.

Assuming that a pixel is classified as «snow> if $50 \%$ or more of the area it represents is covered by snow, those pixels found on the edge of snow-covered areas would represent the snow line belt. Figure 1 indicates which pixels in a slope-situation would be selected as snow line pixels.

\subsection{Processing of NOAA-AVHRR data}

Since 1981 the Remote Sensing Research Group of the Department of Geography, Berne receives and archives NOAA-AVHRR data covering the area of the whole Alps. Since August 2001 we are in an operational status to receive all available NOAA passes with a reliability of almost $100 \%$. Over 16.000 NOAAAVHRR images have been archived, increasing by 5 8 new ones every 24 hours from NOAA-12, NOAA-14, NOAA-15, NOAA-16 and NOAA-17.

Taking into account the amount of NOAA-AVHRR data that has to be processed to analyze changes in alpine snow cover, an operational processing chain is necessary. As interactive processing does not meet with the performance expectations of processing technology today, it cannot be considered an alternative.

The topography of the Alps with its high mountains and steep valleys, as well as the wide-angle characteristic of the AVHRR sensor, are a challenge for remote sensing. These conditions require the development of special modules to process NOAA-AVHRR data preferably in a fully-automated manner. The following modules are part of our processing chain: Calibration of the data, which include a satellite intercalibration of NOAA-9 to NOAA-16 (Teillet \& Holben 1994; RaO \& Chen 1995); automatic geocoding of the data in subpixel accuracy using feature detection; correction of the ortho-shift; terrain normalization (TEILlet et al. 1982);

\footnotetext{
1) For a more comprehensive overview see WUNDERLE, S. \& T. NAGLER (eds) (2001): Remote Sensing of Land Ice and Snow Workshop in Dresden, 16-17 June 2000. - EARSeL eProceedings No. 1, ISBN 2-908885-50-6.
} 


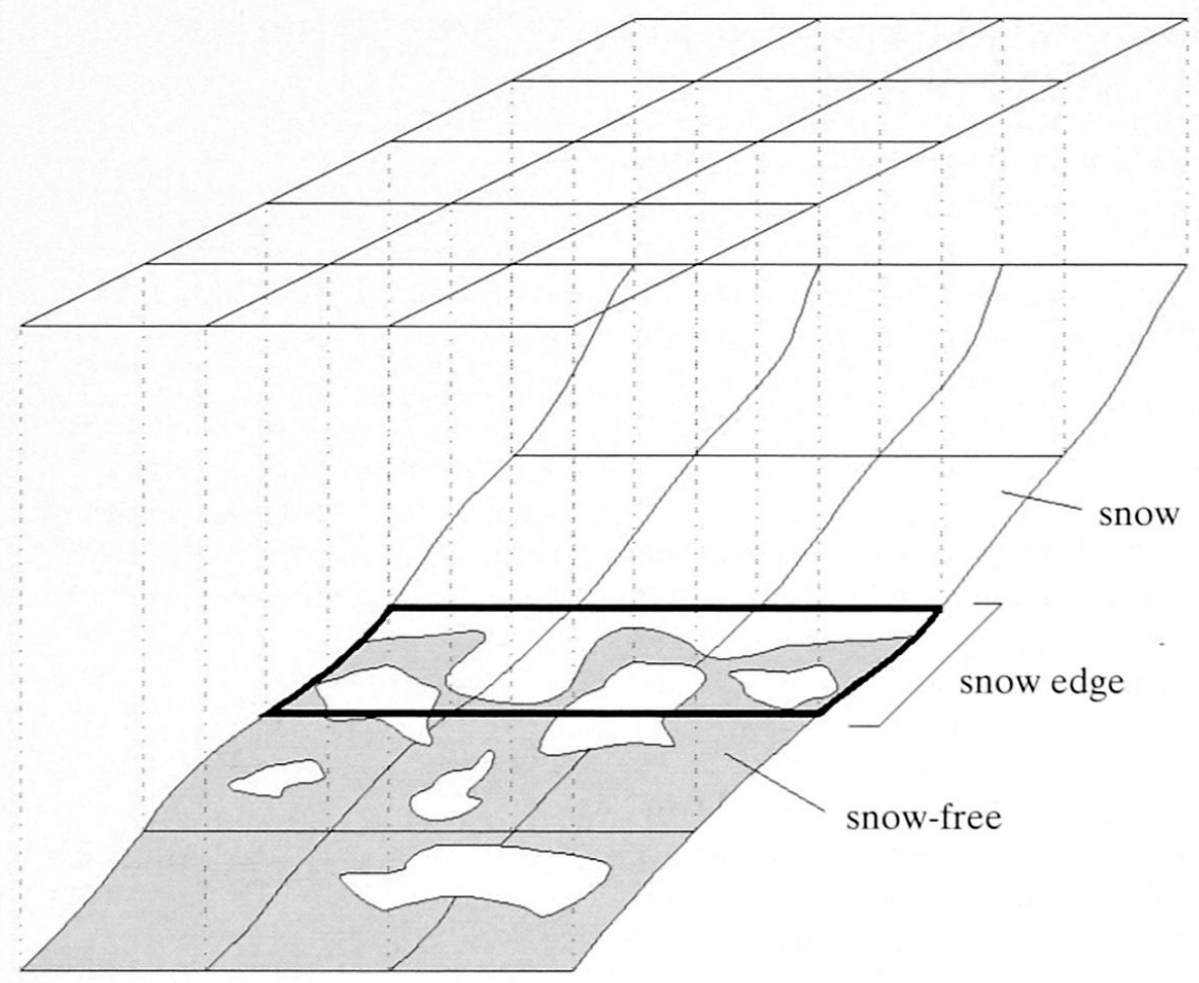

Fig. 1: Schematic view of a slope with snow line. The grid represents the satellite data pixels. The pixels marked with a thick line are defined as snow edge pixels.

Schematische Darstellung eines Hanges mit einer Schneegrenze. Das Raster repräsentiert die Pixelstruktur der Satellitendaten. Die dick umrandeten Pixel sind als Schneerand-Pixel definiert.

Représentation schématique d'un versant à limite nivale. La grille représente les données "pixels» satellitales. Les pixels cerclés en gras sont définis comme des pixels de marges nivales.

atmospheric correction based on 5S (RAHMAN \& DEDIEU 1994); correction of the non-Lambert behavior of the surface using the Bidirectional Reflection Distribution Function (BRDF) (Wu et al. 1995) and computing a cloud mask using the Cloud and Surface Parameter Retrieval (CASPR) of the University of Wisconsin-Madison (KEY 2001) (Figure 2).

The automatic pre-processing of a single image covering the European Alps takes approximately $15-25$ minutes depending on the cloud cover. The thresholds for the module snow/ice are adapted automatically taking into account the time of the year (see Table 1). The pre-processed NOAA-AVHRR data as described in section 2.2 and shown in Figure 2 form the basis for the generation of snow maps.

\subsection{Snow map generation}

Based on the output of the processing chain, further analysis may be conducted. The module SNOW/ICE (see Figure 2) allows the classification of snow covered areas. Using an adapted algorithm, first presented in Gesell (1989), each pixel passes through a multi-step threshold scheme, which works as a negative test. Table
1 lists the different tests and defines default values for each specific test. These threshold values were adapted manually to improve the snow classification for each scene (Droz 2002).

In a first step, all pixels containing information other than snow were eliminated. The resulting bitmap-like snow map illustrates the snow coverage of a particular day (Figure 3). In a next step, the elevation (meters a.s.l.) corresponding to each pixel describing the snow line is determined using a Digital Elevation Model (DEM) with a spatial resolution of $1 \mathrm{~km}$. The GTOPO30 applied is a DEM with a horizontal grid spacing of 30 arc seconds (approximately 1 kilometer) and available for free at the Earth Resources Observation Systems Data Center run by the United States Geological Survey.

\subsection{Inaccuracies in data processing}

Geo-coding

In order to use satellite data in combination with other data sets, like for example a digital elevation model, the satellite data have to be transferred into a common geographical reference system. However, the 
error inherent in the so-called geo-coding process prevents the determination of the exact position of a specific pixel. Generally, an accuracy of about $0.5-1$ pixel may be achieved, which means that NOAA-AVHRR data have an accuracy span of about $500 \mathrm{~m}$ at a resolution of $1.1 \mathrm{~km}$.

Assessing the snow line elevation of a specific slope, for example with an inclination of $45^{\circ}$, a horizontal displacement by as much as $500 \mathrm{~m}$ would lead to the same vertical error of the position of the snow line.

As a consequence, with the errors inherent in the underlying satellite data, no aspect-dependent analysis of snow line elevation is possible. Only if the snow line elevation of complementary aspects is averaged, can the error caused by inaccurate geo-coding be levelled out.

Using hydrological basins as a basis for averaging the elevation data takes advantage of this behavior, since it can be assumed that within a hydrological basin, no aspect dominates. However, the size of the applied basins has to be large enough in order to ensure that a sufficient number of snow edge pixels can be used for statistical analysis.

To be able to test the effect of geo-coding problems, the satellite data applicable for the snow line definition is shifted northwards by one pixel, thus introducing an artificial error. Figure 4 shows that the effect of this manipulation on the snow line elevation distribution is minimal.

\section{Problems due to wrong classification}

The original satellite data consist of digital numbers only, indicating the radiation energy received at the sensor. Using publicly available calibration information, these numbers can be transformed into values with a physical meaning, like albedo or brightness temperature. Classification procedures turn these values or numbers into thematic information, making use of the fact that certain surface types, such as vegetation, water, snow or clouds have specific spectral properties and, therefore, distinct relations between channels with different wavelength sensitivity exist.

Two major difficulties are encountered during the classification procedure. In the case of mixed pixels, which contain two or more surface classes, the assignment to a specific class is sometimes not easy. This is particularly the case for pixels close to the edge of the snow cover. The situation is further complicated by the appearance of the pixels, the factors influencing the appearance being manifold, like the state of the atmosphere, the solar angle or shadow effects.

The second problem lies in the complete misclassifi-

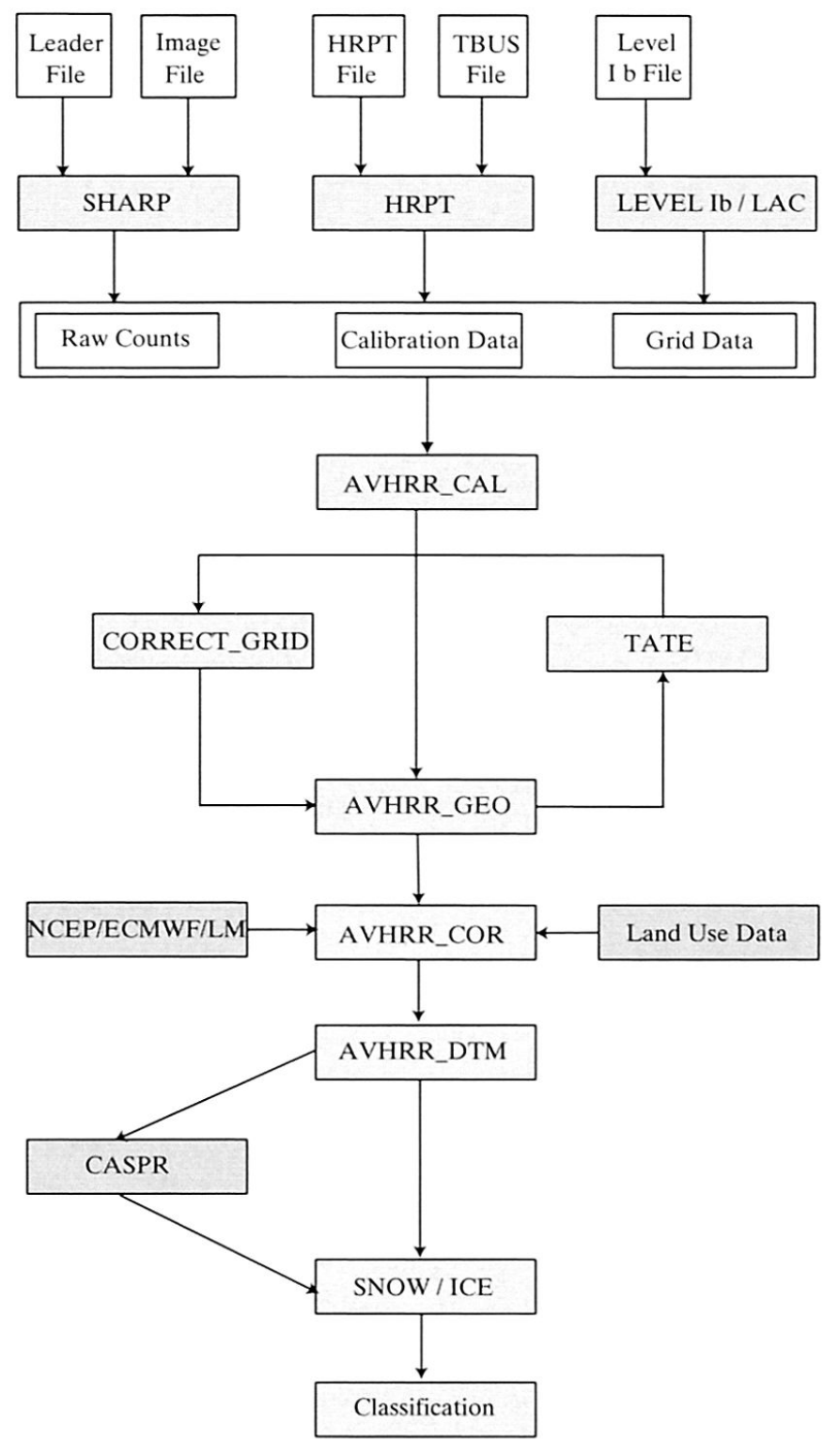

Fig. 2: NOAA-AVHRR processing chain designed for alpine studies with the modules calibration (AVHRR_CAL), geocoding (AVHRR_GEO), atmospheric and BRDF correction (AVHRR_COR), orthorectification (AVHRR_DTM), cloud masking (CASPR), snow classification (SNOW/ICE) and others

Speziell für den Alpenraum entwickelte Prozessierungskette mit den Modulen Kalibration (AVHRR_CAL), Geokodierung (AVHRR_GEO), Korrektur des Atmosphäreneinflusses und Ausgleich von BRDF (AVHRR_COR), Orthorektifizierung (AVHRR_DTM), Erstellung einer Wolkenmaske (CASPR), der Schneeklassifikation (SNOW/ICE) u.a.

Une chaîne de processus spécialement développée pour les études alpines, avec des modules de calibrage (AVHRR_CAL), de géocodification (AVHRR_GEO), de correction de l'influence atmosophérique et de BRDF (AVHRR_COR), d'orthorectification (AVHRR_DTM), de création d'un masque nuageux (CASPR), de classification neigeuse (SNOW/ICE), entre autres. 


\begin{tabular}{|c|l|l|c|}
\hline No. & \multicolumn{1}{|c|}{ Name } & \multicolumn{1}{|c|}{ Definition } & $\begin{array}{c}\text { Typical value } \\
\text { (winter/summer) }\end{array}$ \\
\hline 1. & Warm brightness temperature & $\mathrm{BT}_{4}<\max \mathrm{BT}_{4}$ (snow) & $0^{\circ} \mathrm{C} / 20^{\circ} \mathrm{C}$ \\
\hline 2. & Cold brightness temperature & $\mathrm{BT}_{4}>\min \mathrm{BT}_{4}$ (snow) & $-30^{\circ} \mathrm{C} /-10^{\circ} \mathrm{C}$ \\
\hline 3. & Cirrus & $\mathrm{BT}_{4}-\mathrm{BT}_{5}<\Delta \mathrm{BT}_{45}$ (cirrus) & $2.5^{\circ} \mathrm{K}$ \\
\hline 4. & Vegetation & $\mathrm{NDVI}<\min$ (vegetation) & 0.2 \\
\hline 5. & Water Cloud & $\mathrm{R}_{3}<\max \mathrm{R}_{3}$ (snow) & $8 \%$ \\
\hline 6. & Albedo & $\mathrm{R}_{1}>\min \mathrm{R}_{1}$ (snow) & $20 \%$ \\
\hline
\end{tabular}

Table 1: Typical threshold values recommended for a scene in the Alps early in the year. The suggested values cannot be generally applied. BT (brightness temperature), NDVI (normalised difference vegetation index), $\mathrm{R}_{1} / \mathrm{R}_{3}$ (reflective part of channel 1 and 3 of NOAA-AVHRR)

Die typischen Schwellenwerte sind eine Empfehlung für eine Szene der Alpen, die im Frühjahr aufgenommen wurde. Die vorgeschlagenen Werte können nicht generell eingesetzt werden. BT (Strahlungstemperatur), NDVI (Vegetationsindex), $R_{f} / R_{3}$ (reflektive Anteile in Kanal 1 und 3 von NOAA-AVHRR)

Les valeurs-seuils typiques sont une recommandation pour une scène alpine observée au printemps. Les valeurs proposées ne peuvent pas être appliquées de façon générale. BT (température de rayonnement), NDVI (index de végétation), $R_{f} / R_{3}$ (parts de réflexion dans les canaux 1 et 3 de $N O A A-A V H R R$

cation of a pixel, for example in situations where two objects have a similar spectral behavior. The differentiation between snow and clouds in particular is difficult, especially if low water clouds are involved. This type of misclassification can lead to the definition of snow covered areas at strange elevations.

\section{Definition of the snow line elevation}

Once all the pixels representing the snow line have been marked, the elevation of each can be determined on the basis of a digital elevation model. However, as shown above, because of both the uncertainty of a single pixel's location and the problems concerning snow classification, a certain number of pixels is necessary if a reliable snow line is to be defined on the average of all the pixels.

In order to tackle the problems mentioned above, river basins can be used as reference areas. Using watersheds for this purpose has the great advantage that most aspect classes are represented within the basin areas, leading to more reliable snow line elevation averages. It is important to note that the reference areas have to be large enough if a sufficient number of snow edge pixels are to be made available for a sound statistical analysis. As a test, NOAAAVHRR data with a spatial resolution of $1.1 \mathrm{~km}$ were plotted against IRS-WiFS data with $180 \mathrm{~m}$ resolution, both data representing the situation on $24^{\text {th }}$ March 1999. Thereby, two different sets of reference areas were applied, one with small basins averaging
$145 \mathrm{~km}^{2}$, the other with basins combined to an average of $2340 \mathrm{~km}^{2}$. The results shown in Figure 5 indicate that the size of the first set of reference areas (left plot) is too small. Where larger regions were targeted, an improved agreement between AVHRR and IRSWiFS data could be achieved (right plot). The average difference between AVHRR and IRS-WiFS based snow line elevations could be reduced from $141 \mathrm{~m}$ to $69 \mathrm{~m}$. The maximum deviation improved to $183 \mathrm{~m}$ for the large basins, as compared to $669 \mathrm{~m}$ in the case of the small basins.

\section{First applications and results}

The NOAA-AVHRR sensor is well suited for snow cover monitoring. Its repetition cycle of less than a day allows the mapping of changes in snow cover extent with a sufficiently high temporal resolution. RANGO et al. (1983) claim that the spatial resolution of $1.1 \mathrm{~km}$ is sufficient if large areas of more than $200-500 \mathrm{~km}^{2}$ are targeted, however, an area of $500-1000 \mathrm{~km}^{2}$ and more appears to provide a better statistical data basis (cf. Figure 5). Consequently, our research focussed on the European Alps covering an area of approximately $290.000 \mathrm{~km}^{2}$ (Figure 3) as well as including further regions in Switzerland and Austria.

\subsection{Time series analysis}

Data from three years with different snow cover conditions were selected for the analysis of snow line 


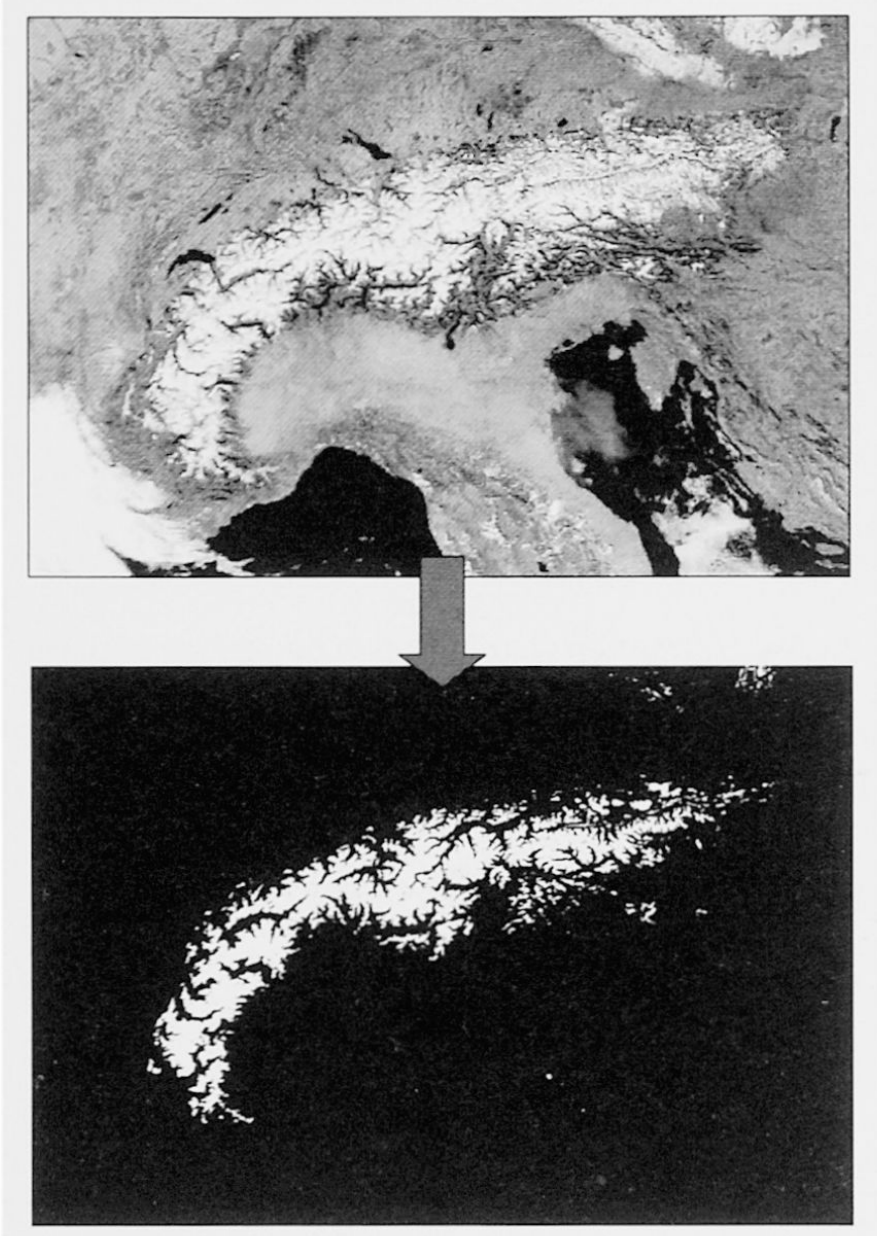

Fig. 3: Automatic snow map generation using the processing chain and the module snow/ice with adapted thresholds defined for different months of the year. This example shows an NOAA- 11 image taken on $20^{\text {th }}$ February 1990 and the thus derived bitmap-like snowmap.

Automatische Erstellung von Schneekarten durch den Einsatz einer Prozessierungskette und dem Modul «snow/ice» mit angepassten Schwellenwerten fiur die verschiedenen Monate im Jahr. Das Beispiel zeigt eine NOAA-11 Aufnahme vom 20. Februar 1990 mit der abgeleiteten Schneekarte.

Confection automatique de cartes nivales au moyen d'une chaîne de processus et du module "snow/ice», avec des valeurs-seuils appropriées pour les divers mois de l'année. L'exemple montre une vue NOAA-11 du 20 février 1990 avec la carte nivale correspondante.

behavior during the ablation periods. Whereas the winter of 1990 was average in terms of snow amount and snow cover duration, 1996 represented mild conditions with only little snow and early ablation in Switzerland. 1999 on the other hand, was dominated by heavy snowfall in February and partly heavy snowfall in April, causing an extended period of snow cover- age, even at lower elevations. The weather of these winter seasons is described in the winter bulletin of the Swiss Federal Institute of Snow and Avalanche Research, Davos but only for Switzerland. The question was whether the snow-conditions in Switzerland applied to the whole alpine area. We therefore processed and analysed the area of the Alps defined by the "Alpenkonvention». The three years defined above were selected to test the usefulness of NOAAAVHRR data to analyse snow line elevation in a large area.

Table 2 shows the number of images available per month for the three ablation periods 1990, 1996 and 1999. The standard of data available for 1996 is best in view of the regularity of data acquisitions (ca. two week rhythm). In 1990, April was to the most part overcast, leading to an acquisition gap of one month. Nevertheless, for all three years there are generally at least two images available per month, thus making comparisons on snow line behavior possible.

The first analysis focused on the alpine area as a whole, thereby minimising possible difficulties concerning the size of the reference areas. During the extreme years 1996 and 1999, the average snow line elevation was calculated as a statistical median of the elevation distribution on each day of observation. Figure $6 \mathrm{com}$ pares the temporal development for three years.

As mentioned above, the selected years represent special situations, early ablation being observed in 1996 and heavy snowfall in 1999. As can be seen in Figure 6, major differences occur during the months of April and May. During these two months, the 1996 snow line was approximately $500 \mathrm{~m}$ higher than in 1999. If the corresponding elevation is compared rather than the corresponding period, then it becomes obvious that snow ablation occurred earlier in 1996 than in 1999. Especially at elevations between $1500 \mathrm{~m}$ and $2500 \mathrm{~m}$, snow ablation in 1999 took place approximately one month later.

It should be pointed out that the snow line behavior in early 1996 was dominated by snow cover in low elevations in the Eastern Alps. The early start of the ablation season in the northern and western part of the Alps in April and May is responsible for the sharp change in the graph curve for 1996.

The high variability of the snow line elevation in January and February 1999 is worth noting. Within two weeks, the snow line rose from $1.600 \mathrm{~m}$ to $2000 \mathrm{~m}$. This could be explained by heavy snowfall mid-February covering large areas at low elevations with a thin layer of snow. As soon as the air temperatures rose slightly end of February, the thin snow cover melted 


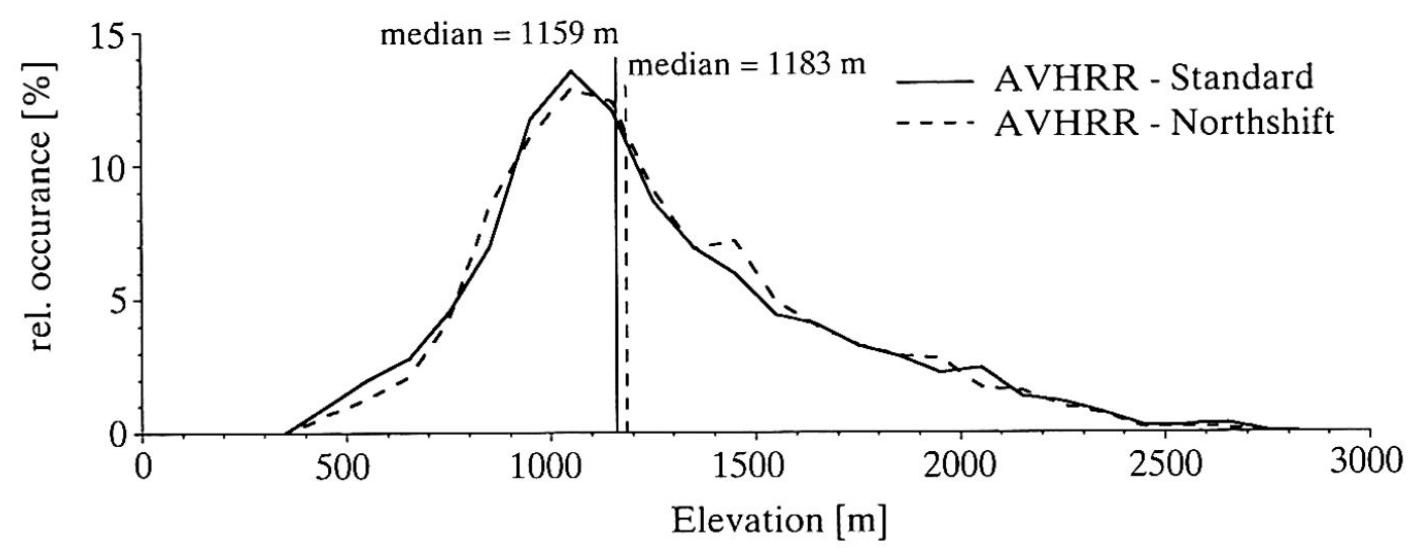

Fig. 4: Effect of a one-pixel north-shift of the snow line on the Swiss elevation distribution of the snow line (based on NOAA-AVHRR data, 24th March 1999)

Auswirkungen einer Nordverschiebung der Schneegrenze um ein Pixel auf deren Höhenverteilung für die ganze Schweiz (basierend auf NOAA-AVHRR Daten vom 24. März 1999)

Répercussions du déplacement d'un pixel du front neigeux vers le nord sur la répartition de celle-ci en altitude pour l'ensemble de la Suisse (base: données NOAA-AVHRR du 24 mars 1999)

and the average snow line elevation increased significantly. 1990 and 1996 did not see such marked changes in snow cover within short periods of time. This could be an indication of more homogeneous weather condi- tions prevailing throughout the Alps during these two years. A more detailed analysis of the variability of the snow line elevation is described in the next chapter (cf. Figure 9).
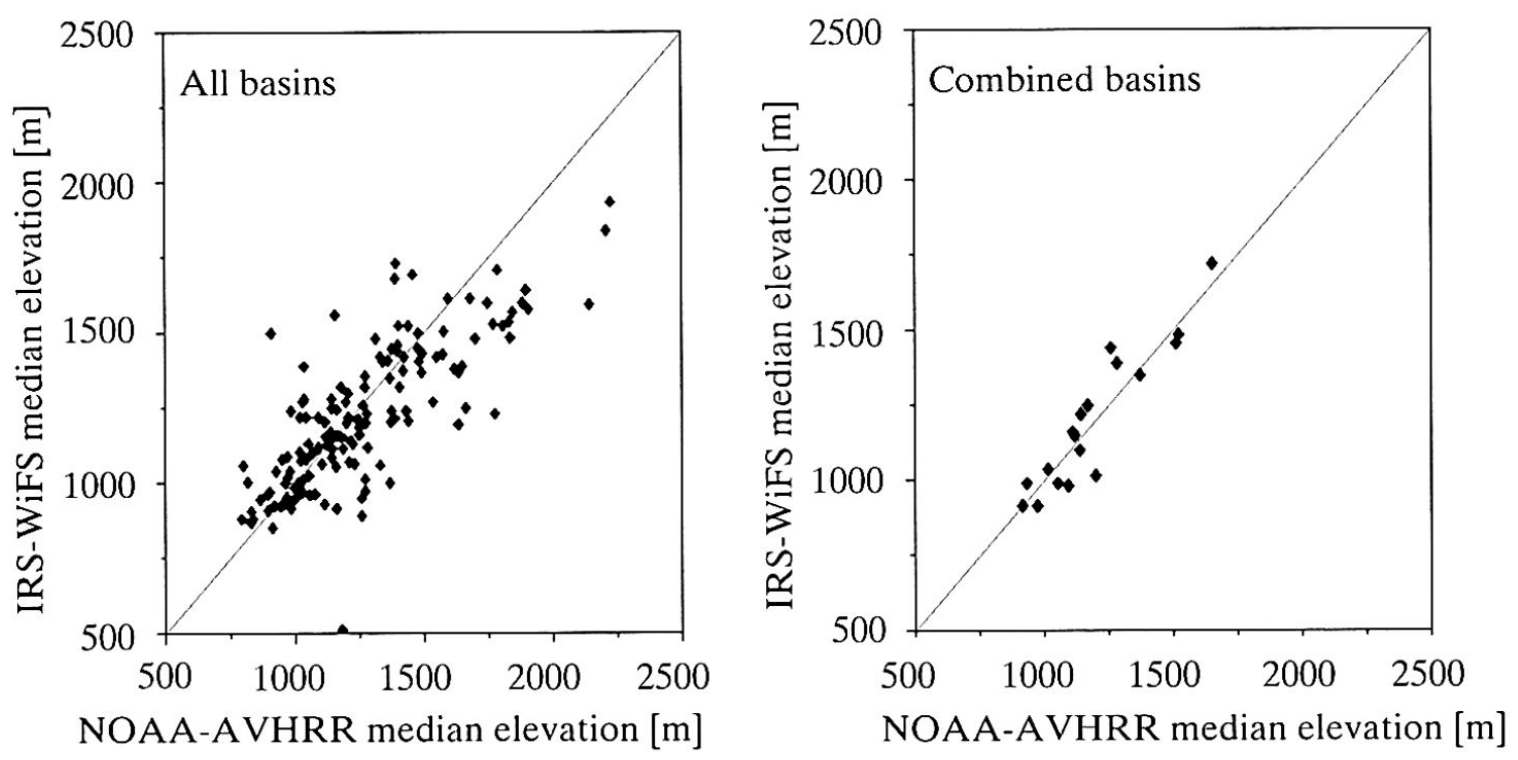

Fig. 5: Comparison of the basin's median snow line elevation based on NOAA-AVHRR and IRS-WiFS data (24 ${ }^{\text {th }}$ March 1999). The left plot shows the result for small basins with an average size of $145 \mathrm{~km}^{2}$. The right plot shows the same data for basins combined to an average of $2340 \mathrm{~km}^{2}$.

Vergleich des Medians der Schneegrenzhöhenverteilung basierend auf NOAA-AVHRR und IRS-WiFS Daten vom 24. März 1999. Die linke Darstellung zeigt den Vergleich für kleine Einzugsgebiete mit einer durchschnittlichen Grösse von $145 \mathrm{~km}^{2}$. Die rechte Abbildung zeigt die gleichen Daten für zusammengefasste Gebiete mit einer Durchschnittsgrösse von $2340 \mathrm{~km}^{2}$.

Comparaison de la distribution moyenne de la limite nivale en altitude, selon les données NOAA-AVHRR et IRS-WiFS du 24 mars 1999. La représentation de gauche permet la comparaison de petits périmètres ayant une superficie moyenne de $145 \mathrm{~km}^{2}$. Celle de droite indique les mêmes données pour des territoires d'une superficie moyenne de $2340 \mathrm{~km}^{2}$. 


\begin{tabular}{|l|c|c|c|c|c|c|c|c|c|c|c|}
\hline & Jan & Feb & Mar & Apr & Mai & Jun & Jul & ANZ & AVG $\triangle$ & SDV $\triangle$ & MAX $\Delta$ \\
\hline $\mathbf{1 9 9 0}$ & 02 & 07 & 07 & & 01 & 16 & 23 & 16 & 13.4 & 8.9 & 31 \\
& 11 & 20 & 17 & & 02 & 25 & & & & & \\
& 22 & & 19 & & 29 & & & & & & \\
& & & 31 & & 31 & & & & & & \\
\hline 1996 & 08 & 09 & 04 & 16 & 06 & 06 & 03 & 26 & 8.2 & 4.6 & 17 \\
& 16 & 24 & 20 & 19 & 16 & 15 & 12 & & & & \\
& 19 & 28 & 31 & & 24 & 28 & 18 & & & & \\
& 30 & & & & 30 & & 19 & & & & \\
& & & & & & & 25 & & & & \\
& & & & & & & 26 & & & & \\
\hline 1999 & 06 & 02 & 02 & 06 & 01 & 01 & 02 & 22 & 9.5 & 5.4 & 22 \\
& 15 & 15 & 13 & 10 & 03 & 09 & 24 & & & & \\
& 24 & 25 & 18 & 25 & 24 & 25 & & & & & \\
& & & 21 & & & & & & & & \\
\hline
\end{tabular}

Table 2: Selected and analysed NOAA-AVHRR images of the ablation seasons 1990, 1996 and 1999. ANZ denotes the number of images, AVG is the average time gap between two shots (in days), SDV is the standard deviation of AVG and MAX indicates the longest time gap between two successive images.

Ausgewählte und bearbeitete Satellitenszenen der Ausaperungsperioden 1990, 1996 und 1999. ANZ entspricht der jeweiligen Anzahl an Aufnahmen, AVG der durchschnittlichen Zeitperiode (Tage) zwischen zwei Aufnahmen, $S D V$ der Standardabweichung dieser Abstände und MAX steht für die maximale Zeitdifferenz zweier Bilder.

Choix d'images satellitales élaborées pour les saisons d'ablation 1990, 1996 et 1999. ANZ correspond au nombre respectif d'observations, $A V G$ à l'intervalle moyen (en jours) entre deux observations, SDV à l'écart standard de ces intervalles et $M A X$ à la durée maximale qui sépare deux images.

\subsection{Spatial pattern of snow line behavior}

In principle, the analysis and interpretation of the behavior of snow line evolution for the Alps as a whole is rather speculative due to the climatic differences between the western and eastern part of the Alps. Consequently, we divided the alpine area into 55 subregions, the results of three of these regions discussed here (Figure 7). The first step was to compare the average snow line elevation of each region with the total alpine average for each day recorded by satellite. The elevation differences between the two scales were then averaged using data from all available observations during the three years. However, the normative approach using alpine averages is not absolutely reliable. Partial cloud cover over the Alps can cause a bias, particularly if clouds obscure a region with extraordinary high snow line elevations. This method is, therefore, only an approximate way of defining regions with similar climatic conditions.

The partition of the Alps was based on hydrological catchments taking into account that every sub-region should exceed the minimum of 3000 pixels to fulfil statistical requirements (cf. Figure 5). The amount of pixels in the different catchments differs between 3200 and 8600 with a mean of 5911 pixels. The delimitation of the Alps was done according to the «Alpenkonvention" and after Bätzing (1993). The focus on three sub-regions «Chablais» (exposed to north-west), "Aosta Valley» (a dry valley in the central Alps) and «Pinzgau» (representative for the eastern part of the Alps) allowed for a more detailed look at climatic differences and therefore more precise statements on snow line elevation. The analysis was done for the years 1990, 1996 and 1999 (Figure 8).

As mentioned before, the snow line elevation of every subregion was compared with the evolution of the snow line of the whole alpine area. As can be seen in Figure 8, there are significant differences between the regions. On the whole, the snow line behavior of the Chablais and Pinzgau regions is similar to the alpine average during all three years. However, if attention is paid to the individual graph dots, the snow line in Chablais is noticeably low in January and February, indicating early snow in this part of the Alps. However, in January 1990, the snow line in Pinzgau was roughly 200 meters lower than in Chablais. This could be an indication that snow cover in the Eastern Alps lasts longer than in the rest of the Alps. After snowfall 


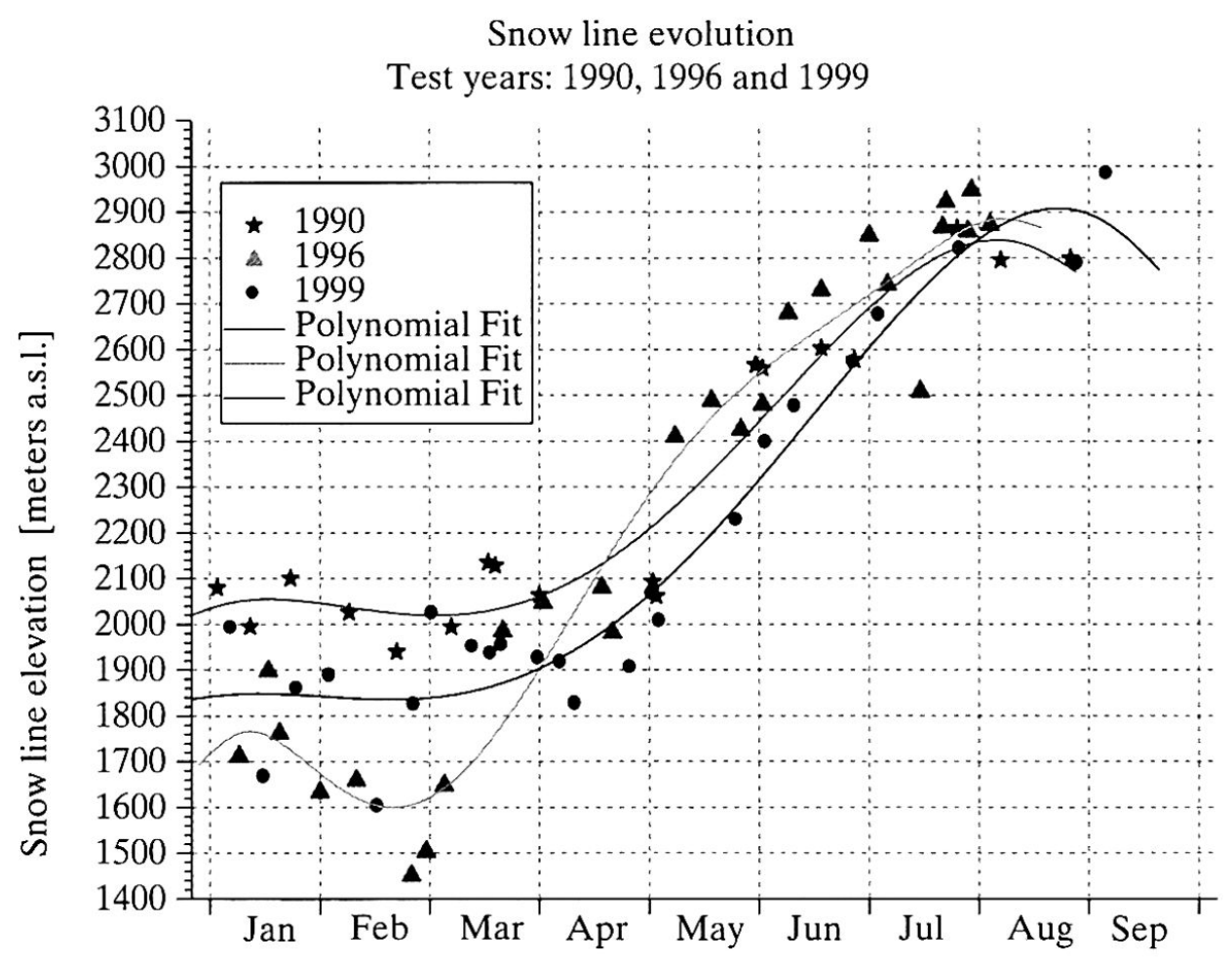

Fig. 6: Snow line evolution in the European Alps during 1990, 1996 and 1999. The lower position of the snow line in January until March 1996 and the fast ablation during March and April are clearly visible.

Die Entwicklung der Schneegrenze für die europäischen Alpen der Jahre 1990, 1996 und 1999. Die tiefe Lage der Schneegrenze im Januar bis März 1996 und die schnelle Ablation im März und April sind klar zu erkennen.

L'évolution de la limite neigeuse dans les Alpes européennes en 1990, 1996 et 1999. La basse altitude de la limite neigeuse de janvier à mars 1996 et l'ablation rapide de mars-avril sont clairement perceptibles.

in February, the situation in the two regions was similar. During the three years selected, fluctuation of the snow line according to the graph dots was less pronounced for the Aosta Valley than for Chablais and Pinzgau.

The snow line average of the Aosta Valley is significantly different to the rest of the Alps. During all three years the snow line was approximately $200-300 \mathrm{~m}$ above the average, high irradiation and low local precipitation rates being the main causes for the difference. The high inter annual variability of the weather (RANZI et al. 1999) certainly also plays a role.

In order to better understand the snow line behavior, maximum and minimum values (triangles) were added to the graphs (Figure 9). The circles indicate the mean values. As a result, the seasonality of the variability range was more apparent. Thus, this approach proved to be better suited for illustrating snow line elevation variability. For example, it became apparent that the variability is higher at the beginning of winter than during the ablation phase at the end of winter, espe- cially in the southern and eastern part of the Alps (Figure 9).

Both snow cover and snow line are strongly influenced by different climate parameters. However, as individual situations are influenced by single snowfall events, they do not necessarily represent a general behavior. Figure 9 summarises the analysis of the snow line over three years.

Considering the importance of snow cover for alpine tourism, it should be pointed out that within a region, the differences between the ski resorts concerning snow line elevation can be very high, especially in the eastern part of the Alps. The central Alps do not offer good skiing conditions under $2.400 \mathrm{~m}$.

In addition, the high variability of the snow line elevation in the Eastern Alps makes water management in this area difficult. Farming and hydropower generation depend on snow cover as a source of water - the unreliability of the source leading to greater financial risk. 


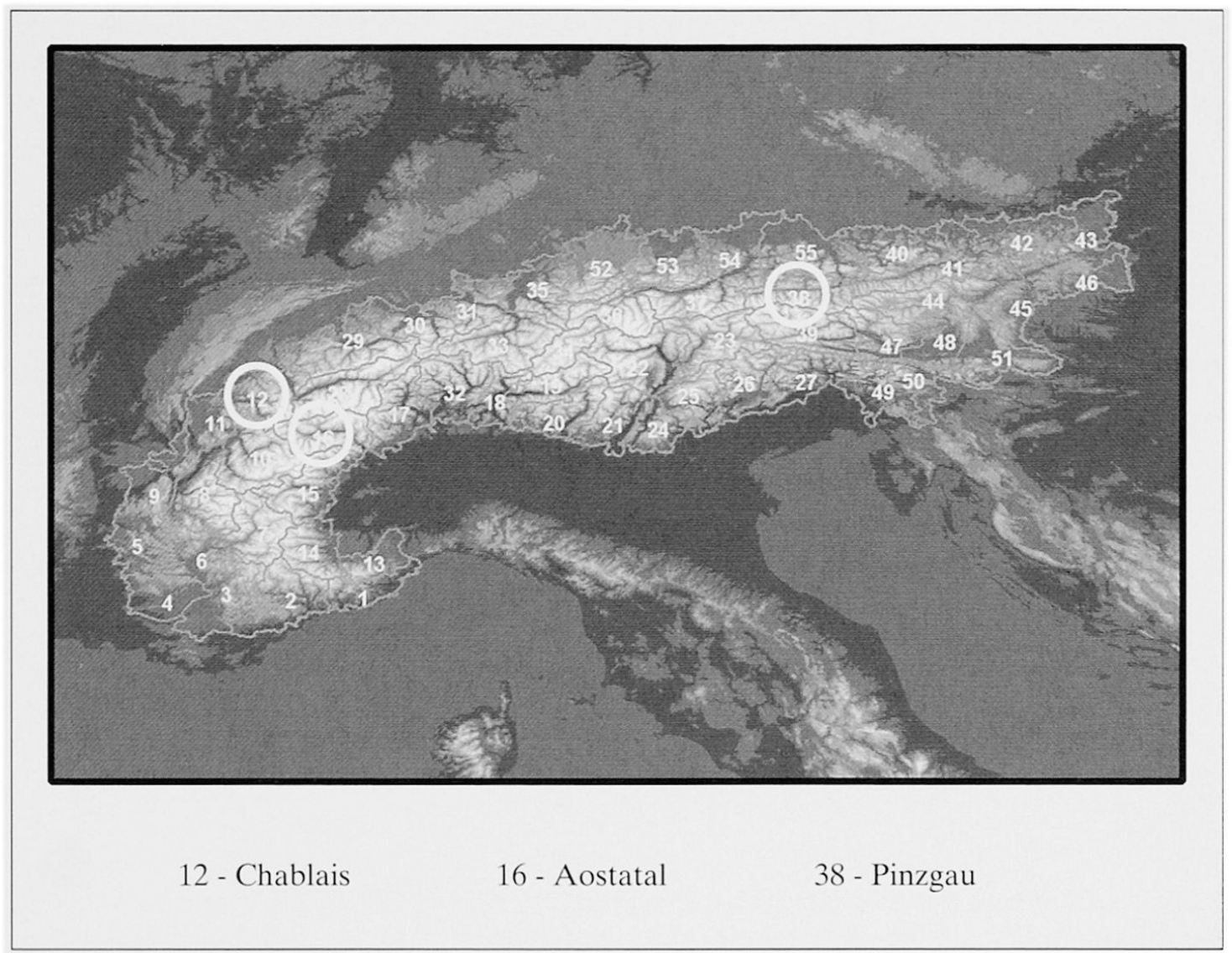

Fig. 7: 55 subregions of the European Alps based on hydrological catchments. The delimitation of the Alps was done according to the "Alpenkonvention» and BätzING (1993). Special attention was paid to the three subregions «Chablais» (outer North-Western Alps), «Aosta Valley» (dry valley in the Central Alps) and «Pinzgau» (Eastern Alps).

Die Untergliederung des Alpenraums in 55 Subregionen. Die Einteilung erfolgt anhand von Einzugsgebieten, die Abgrenzung gemäss Alpenkonvention sowie nach BäTZING (1993). Die Analyse auf subregionaler Ebene basiert auf den Regionen "Chablais» (randliche Nordwestalpen), Aostatal (inneralpines Trockental) und Pinzgau (Ostalpen).

Le classement des Alpes en 55 sous-régions. La répartition est fonction du périmètre des bassins; la délimitation est conforme à la Convention des Alpes et à la publication de BäTZING (1983). L'analyse à l'échelle subrégionale est fondée sur les régions "Chablais» (périphérie des Alpes nord-occidentales), "Val d'Aoste» (vallée sèche intraalpine) et «Pinzgau» (Alpes orientales).

\subsection{Discussion and outlook}

The application of satellite data for snow line elevation assessment according to the method described above appears to be very promising. Figures 8 and 9 show that the temporal snow line signature can be used to identify regions with different snow line behavior. The experiences described in this article can, therefore, be seen as the first steps towards creating a snow climatology of the Alps, advances in this field requiring the inclusion of further data and several more years of snow line monitoring.

As only three years were taken into consideration, a first comparison with the circulation pattern of the
Northern Hemisphere shows that there was no clear correlation between snow cover and circulation. We used the North Atlantic Oszillation Index (NAOI) which measures the air pressure difference between the Azores and Island. The mean difference of the months December to March was for 1990 and 1999 almost identical (ca. +1.4), whereas the value for 1996 was -1.8 . Thus, if we presume there to be a correlation between air pressure difference and snow cover, then it will be necessary to work with a time series of NOAAAVHRR data and not with individual years.

Before more detailed research in this field can continue, some of the problems addressed above have 

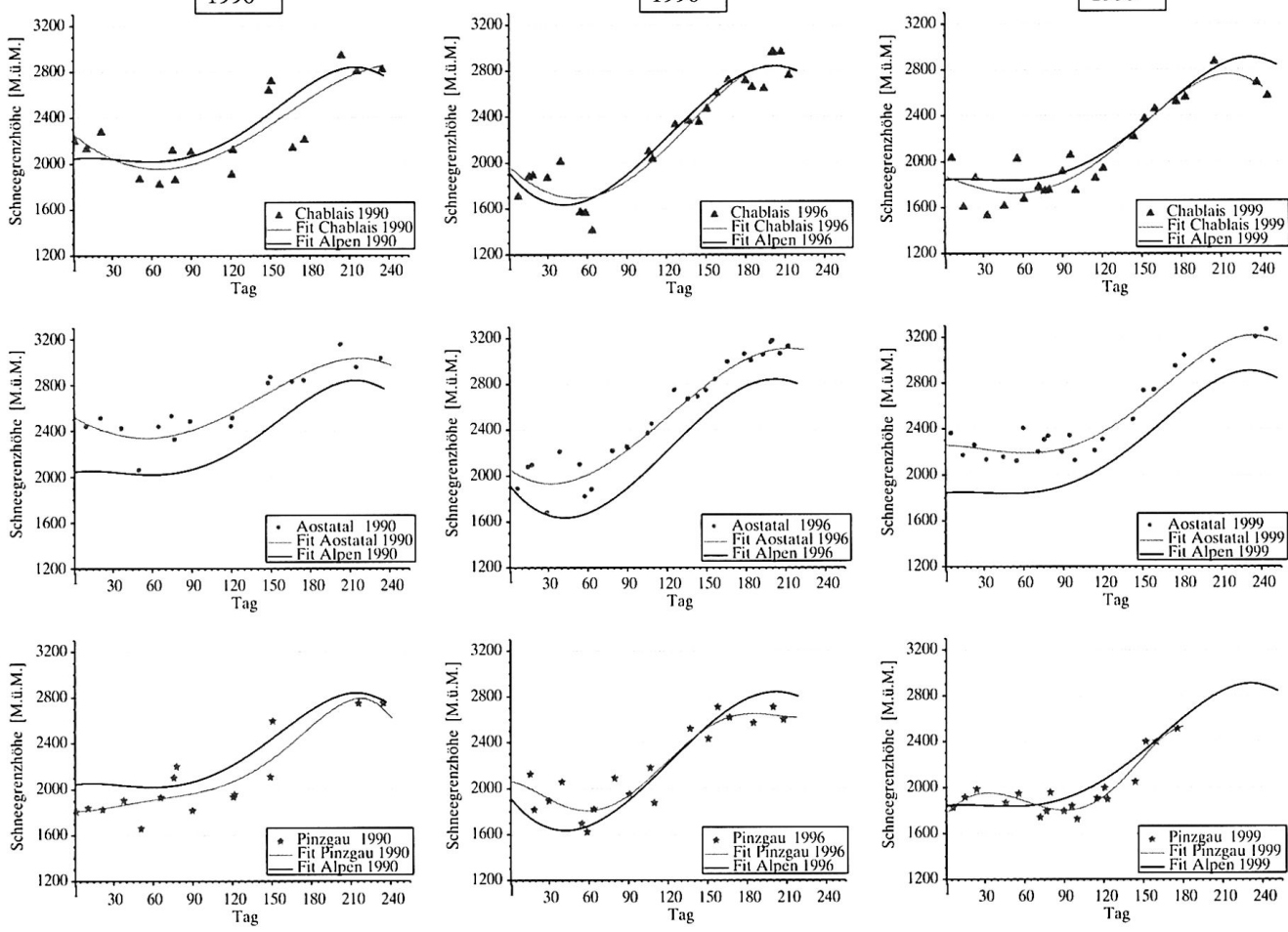

Fig. 8: The snow line evolution in the regions «Chablais» (top row), Aosta Valley (middle row) and «Pinzgau» (bottom row) indicate differences in climatic behavior in the Alps. Worth mentioning is the higher snow line elevation in the inner alpine regions. Day 1 denotes the first of January.

Die Schneegrenz-Signaturen der drei Regionen "Chablais» (oben), Aostatal (Mitte) und Pinzgau (unten) dokumentieren unterschiedliche Klimaregime in den alpinen Regionen. Markant ist die permanent höher liegende Schneegrenze in inneralpinen Tälern. Tag I entspricht jeweils dem 1. Januar:

L'évolution de la limite neigeuse des trois régions "Chablais" (en haut), "Val d'Aoste» (au milieu) et "Pinzgau» (en bas) témoigne des régimes climatiques différenciés dans les régions alpines. Il convient de souligner le fait que dans les vallées intraalpines la limite neigeuse permanente supérieure est située à une altitude plus élevée qu'ailleurs. Le premier jour correspond au 1. janvier. 

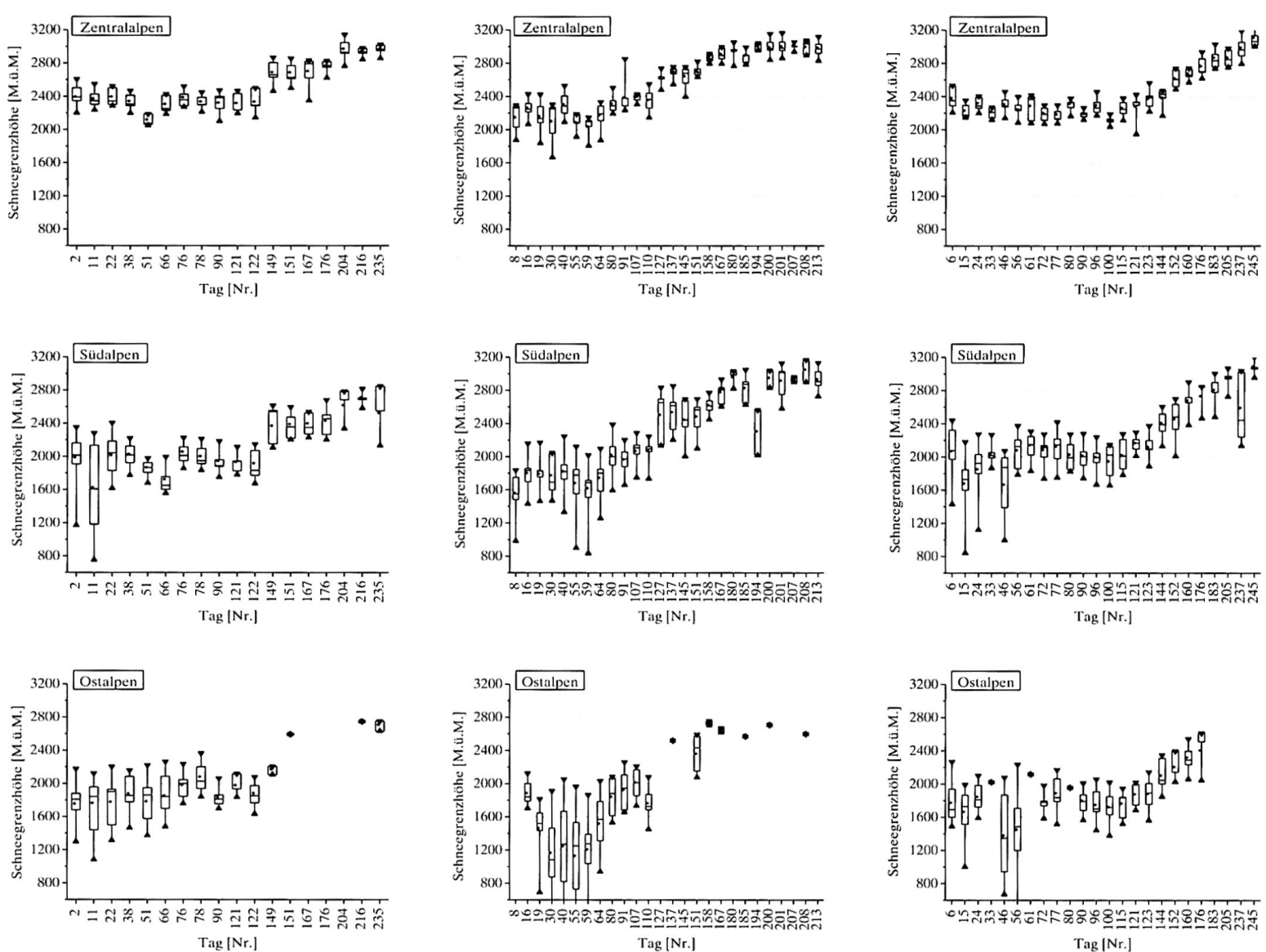

Fig. 9: Legend see next page 
Legend fig. 9: Mean behavior of snow line elevation in the Central Alps (upper row), Southern Alps (middle) and Eastern Alps (lower row) for the years 1990 (left), 1996 (middle) and 1999 (right). The circle represents the mean values, the triangle the maximum and minimum values and the box depicts the lower and upper quartile. Entwicklung der Schneegrenzhöhe für die Zentralalpen (oben), Südalpen (Mitte) und Ostalpen (unten) für die Jahre 1990 (links), 1996 (Mitte) und 1999 (rechts). Im Kastendiagramm ist der Mittelwert mit einem Punkt dargestellt, Minimum und Maximum als Dreieck und die «box» zeigt das obere und untere Quartil.

Evolution de l'altitude de la limite neigeuse dans les Alpes centrales (en haut), les Alpes méridionales (au milieu) et les Alpes orientales (en bas), en 1990 (à gauche), 1996 (au centre) et 1999 (à droite). En ce qui concerne le diagramme du cartouche, la valeur moyenne est indiquée par un point, les minima et maxima par un triangle, le "box» exprimant les quartiles supérieur et inférieur.

to be resolved. The misreading of clouds and snow is still a problem, even though the NOAA-AVHRR can to some extent discern between snow and cloud. A promising step was the development of threshold sets for the three seasons winter, late winter and spring/summer. Consequently the classification results improved significantly over the results using threshhold values according to Gesell (1989). Compared with results derived from distributed snow modelling (Weibel et al. 2002) and Landsat-TM data (Droz 2002), the snow covered area was underestimated. A further improvement can be obtained using atmospheric temperature at different levels to adapt the thresholds automatically to the daily atmospheric conditions. Furthermore, it will be necessary to test whether statistical methods or GIS approaches should be applied to mask out those elevations defined as a result of misclassification.

In summary, the method presented describes an operational approach to deriving snow lines and their corresponding elevations using NOAA-AVHRR data. For the first time the temporal and spatial behavior of snow cover at the scale of the European Alps was investigated. The advantage of NOAA-AVHRR data for snow cover monitoring of large areas in complex terrain could be verified.

\section{References}

BäTZING, W. (1993): Der sozio-ökonomische Strukturwandel des Alpenraumes im 20. Jahrhundert. Eine Analyse von «Entwicklungstypen» auf GemeindeEbene im Kontext der europäischen Tertiarisierung. Geographica Bernensia (P26).

Baumgartner, M.F., Schönenberger, A. \& U. StalDER (1991): Snow cover variations in the Alps using NOAA-AVHRR data. - In: BergmanN, H., LANG, H.,
Frey, W., IsSLer, D. \& B. SAlm (eds): Snow, Hydrology and Forests in High Alpine Areas. - In: International Association of Hydrological Sciences Publication 205: 41-50.

CARroll, T.R. (1990): Operational Airborne and Satellite Snow Cover Products of the National Operational Hydrologic Remote Sensing Center. - In: Proceedings of the Forty-Seventh Annual Eastern Snow Conference, Bangor, Maine: 87-98.

Droz, M. (2002): Analyse der Schneegrenze im Alpenraum basierend auf NOAA-AVHRR Daten.-Diplomarbeit, Geographisches Institut der Universität Bern. Ehrler, C. \& J. Schaper (1997): Analyse von Ausaperungsmustern der saisonalen Schneedecke mit Fernerkundungsmethoden. - In: Geographica Helvetica 52, 1:11-20.

Gesell, G. (1989): Analgorithm for snow and ice detection using AVHRR data - an extension to the Apollo software package. - International Journal of Remote Sensing 10 (4-6): 897-905.

KeY, J.R. (2001): The Cloud and Surface Parameter Retrieval (CASPR) System for Polar AVHRR. User's Guide, NOAA/NESDIS/ORA/ARAD/ASPT, 2001.

Kleindienst, H., Pfister, M. \& M.F. Baumgartner (1999): Pre-operational snowmelt forecasting based on an integration of ground measurements, meteorological forecasts and satellite data. - In: Tranter, M., Armstrong, R., Brun, E., Jones, B., Sharp, M. \& M. Williams (eds): Interactions between the Cryosphere, Climate and Greenhouse Gases. - In: IAHS Publ. 256: 81-89.

Pietroniro, A. \& R. Leconte (2000): A review of Canadian remote sensing applications in hydrology, 1995-1999. - Hydrological Processes 14(10): 1641-1666.

Rahman, H. \& G. Dedieu (1994): SMAC: a simplified method for the atmospheric correction of satellite 
measurements in the solar spectrum. - International Journal of Remote Sensing 15(1): 123-143.

RANGO, A. (1993): Snow hydrology processes and remote sensing. - Hydrological Processes 7: 121-138.

Rango, A., Martinec, J., Foster, J. \& D. Marks (1983):

Resolution in operational remote sensing of snow cover. - In: IAHS Publ.145: 371-381

RANZI, R., Grossi, G. et al. (1999): Ten years of monitoring areal snowpack in the Southern Alps using NOAA-AVHRR imagery, ground measurement and hydrological data. - Hydrological Processes 13(12-13): 2079-2095.

RAO, C.R.N. \& J. CHEN (1995): Inter-satellite calibration linkages for the visible and near-infrared channels of the Advanced Very High Resolution Radiometer on the NOAA-7, -9 and -11 spacecraft. - In: International Journal of Remote Sensing 16: 1931-1942.

Seidel, K., Ehrler, C., Martinec, J. \& O. Turpin (1997): Derivation of statistical snow line from highresolution snow cover mapping. - In: WUNDERLE, S. (ed.): Remote Sensing of Land Ice and Snow. $-=$ Proceedings of the EARSeL Workshop, 31-36, Freiburg. Teillet, P., Guindon, B. et al. (1982): On the Slope/ Aspect Correction of Multispectral Scanner Data. Canadian Journal of Remote Sensing 8(2): 84-106.

Teillet, P.M. \& B.N. Holben (1994): Towards Operational Radiometric Calibration of NOAA AVHRR Imagery in the Visible and Near-Infrared Channels. Canadian Journal of Remote Sensing 20(1): 1-10.

Weibel, D., Wunderle, S. \& H. Kleindienst (2002): A distributed model to simulate the snow cover in Switzerland combining GIS and RS. - In: Proceedings of the EARSeL Symposium, Prague 2002 (in print).

Wu, A., Li, Z. et al. (1995): Effects of land cover type and greenness on advanced very high resolution radiometer bidirectional reflectances: analysis and removal. Journal of Geophysical Research 100(5D): 9179-9192.

\section{Summary: Spatial and Temporal Analysis of the snow Line in the Alps Based on NOAA-AVHRR Data}

A method to derive the snow line elevation using NOAA-AVHRR satellite data in combination with a digital elevation model is presented. The AVHRR sensor enables the frequent observation of snow cover with a sufficiently high temporal resolution.

The definition of the snow line and the impact of geocoding errors, as well as errors due to misclassification, are discussed. A comparison of the NOAA-AVHRR data with data from the higher resolution IRS-WiFS indicates that even at a spatial resolution of $1.1 \mathrm{~km}$, a quantitative analysis of the snow line elevation is possible.

The influence of different winter conditions in Switzerland on the elevation of the snow line is reflected in satellite data from 1990, 1996 and 1999. The results of the investigation were, firstly the presentation of the spatial pattern of the average snow line elevation, secondly the derivation of snow line signatures for three regions. These were then compared with the overall alpine snow line signature.

\section{Zusammenfassung: Räumliche und zeitliche Analyse der Schneegrenze in den Alpen, abgeleitet aus NOAA-AVHRR Aufnahmen}

Eine Methode zur Ableitung der Schneegrenzhöhe mittels NOAA-AVHRR Satellitendaten in Kombination mit einem digitalen Höhenmodell wird gezeigt. Der AVHRR Sensor ermöglicht eine häufige Beobachtung der Schneedecke mit ausreichender zeitlicher Auflösung.

Die Definition der Schneegrenze sowie die Auswirkung von Geokodierungs- und Klassifikationsfehlern wird diskutiert. Ein Vergleich der NOAA-AHVRR Daten mit räumlich besser auflösenden IRS-WiFS Daten zeigt, dass auch eine räumliche Auflösung von $1.1 \mathrm{~km}$ eine quantitative Analyse der Schneegrenzhöhe ermöglicht.

Satellitendaten der Jahre 1990, 1996 und 1999 zeigen den Einfluss unterschiedlicher winterlicher Bedingungen in der Schweiz auf die Höhe der Schneegrenze. Als erstes Ergebnis wird das räumliche Muster der mittleren Schneegrenzhöhe dargestellt. Weiterhin werden die Schneegrenzsignaturen, die das Ansteigen der Schneegrenze mit der Zeit charakterisieren, für drei Regionen dargestellt und mit der alpenweiten Schneegrenzsignatur verglichen.

\section{Résumé: Analyse spatio-temporelle de la limite nei- geuse dans les Alpes (Base de données: NOAA- AVHRR)}

L'article présente une méthode de détermination de l'altitude de la limite neigeuse à partir des données satellitales NOAA-AVHRR, en combinaison avec un modèle d'altitude digital. AVHRR facilite une observation assidue de la couverture neigeuse dans une durée pertinente.

La présente étude porte également sur la définition de la limite neigeuse, ainsi que sur les répercussions des erreurs de codification géographique et de classification. La comparaison des données NOAA-AVHRR avec les données spatialement plus expressives d'IRSWiFS montre qu'un segment de $1.1 \mathrm{~km}$ permet aussi une analyse quantitative de l'altitude de la limite neigeuse.

Les données satellitales des années 1990,1996 et 1999 montrent l'influence de conditions hivernales différenciées sur l'altitude de la limite neigeuse en Suisse. Un 
premier résultat de la recherche est constitué par le modèle spatial de l'altitude moyenne de la limite neigeuse. D'autres résultats relatifs à la limite neigeuse révèlent l'influence du facteur «temps» dans l'extension de cette limite, à partir de trois régions en comparaison avec la limite neigeuse propre à l'ensemble de l'arc alpin.

Dr. Stefan Wunderle, Department of Geography, University of Berne, Hallerstrasse 12, $\mathrm{CH}-3012$ Berne.

e-mail: swun@giub.unibe.ch

Dipl. Geogr. Marcel Droz, Chutzenstrasse 39, CH-3007

Bern.

e-mail:mdroz@dplanet.ch

Dr. Hannes Kleindienst, Gruner AG, Margarethenstrasse 77, CH-4020 Basel.

e-mail: Hannes.Kleindienst@gruner.ch

Manuskripteingang/received/manuscrit entré le

2.5.2002

Annahme zum Druck/accepted for publication/accepté pour l'impression: 20.9.2002 